\title{
Article \\ The Effect of U.S. Investor Sentiment on Cross-Listed Securities Returns: A High-Frequency Approach
}

\author{
Juan Pablo Gutierrez Pineda ${ }^{1, *}$ and Daniel Perez Liston ${ }^{2}$ \\ 1 Department of Accounting and Finance, School of Business and Public Administration, California State \\ University, Bakersfield, CA 93311, USA \\ 2 Economics, Finance, and Decision Information Systems, University of Saint Thomas, Houston, TX 77006-4626, \\ USA; drperez@stthom.edu \\ * Correspondence: jgutierrez-pineda@csub.edu
}

Citation: Gutierrez Pineda, Juan

Pablo, and Daniel Perez Liston. 2021. The Effect of U.S. Investor Sentiment on Cross-Listed Securities Returns: A High-Frequency Approach. Journal of Risk and Financial Management 14: 491 https://doi.org/10.3390/ jrfm14100491

Academic Editor: Joanna Olbryś

Received: 12 August 2021

Accepted: 7 October 2021

Published: 15 October 202

Publisher's Note: MDPI stays neutral with regard to jurisdictional claims in published maps and institutional affiliations.

Copyright: (c) 2021 by the authors. Licensee MDPI, Basel, Switzerland. This article is an open access article distributed under the terms and conditions of the Creative Commons Attribution (CC BY) license (https:// creativecommons.org/licenses/by/ $4.0 /)$

\begin{abstract}
This paper studies the impact of a high-frequency investor sentiment measure (New FEARS) on the returns of foreign securities listed in U.S. markets as American Depository Receipts (ADRs). We recreate a high-frequency investor sentiment measure by aggregating search volume indices (SVIs) for a set of negative economic search terms. We find that ADR aggregate market returns exhibit a negative reaction to increases in searches for negative economic terms such as "recession", "crisis", and "bankruptcy" by U.S. households. This is the first paper to measure the effects of high-frequency investor sentiment on cross-listed securities. Moreover, the results are consistent throughout our study regardless of the variation of sentiment and aggregate market return measure we use. We also explore ADR regional market indices and show that Latin American ADRs are more sensitive to this investor sentiment measure.
\end{abstract}

Keywords: american depositary receipts; investor sentiment; search volume index

\section{Introduction}

There is a long running debate in the asset pricing literature on the role that investor sentiment plays in financial markets. For instance, Keynes (1936) coined the term "animal spirits" to describe investors' enthusiasm regarding certain assets. He believed that animal spirits sometimes overtook markets and thus moved asset prices away from their fundamental values. Evidence provided by De Long et al. (1990), Barberis et al. (1998), Baker and Wurgler (2006), Perez-Liston and Gutierrez (2018), and many others has established a clear link between investor sentiment and asset prices. As a result of this evidence, the debate has shifted to which investor sentiment measures are more appropriate when measuring the impact of investor sentiment on asset prices (Baker and Wurgler 2007).

In this study, we examine the effect of a U.S.-based investor sentiment measure called FEARS (Financial and Economic Attitudes Revealed by Search) on American Depositary Receipts (ADRs) returns; the FEARS index was developed by Da et al. (2015). Furthermore, we seek to determine the role of U.S. investor sentiment in the asset pricing model of foreign securities through the aggregate market of cross-listed security indices, both in general and regionally.

ADRs are negotiable certificates that represent a piece of ownership in a foreign company. These instruments were created to facilitate the trading of non-U.S. companies stock in U.S. capital markets. Previous studies suggest that not only are they a good way to invest in foreign companies, but they also allow U.S. investors to obtain diversification benefits by including ADRs in their portfolios (Jiang 1998; Alaganar and Bhar 2001).

We are particularly interested in studying ADRs because the securities are simultaneously listed in two geographically different financial markets: the home country and in the U.S. In both markets, the asset is subject to the same set of company fundamentals and similar idiosyncratic risk, but different macroeconomic conditions, risk premia, and investor 
sentiment (Suh 2003; Grossmann et al. 2007). It is important for portfolio managers that seek international diversification through investing in ADRs to understand the short-term spillover effects of U.S. investor sentiment on these securities.

Since the FEARS measure is a high-frequency proxy for investor sentiment, we deem ADRs preferable to underlying securities to minimize the effect of non-synchronous trading; especially in the case of European and Asian ADRs, which trade at very different hours than U.S. markets. This difference is particularly relevant when measuring the impact of daily investor sentiment. If we want to capture the contemporaneous effect of U.S. investors' sentiment in foreign securities, we must measure its effect while markets are still open. For example, an increase in negative U.S. investor sentiment may not be reflected until the next trading day in the case of Asian or European markets, at which time the effect may have been diminished or different news could have a different impact on the underlying assets markets and the investors' sentiment altogether. Finally, because of its simplicity, the ADR program is widely adopted in the U.S. financial system, which means that most international stock buy/sell transactions take place using ADRs as a vehicle, not the underlying stocks.

Traditionally, investor sentiment proxies used in previous research belong to either the "bottom-up" survey-based approach originally used by Brown and Cliff (2004) or the "top-down" approach introduced by Baker and Wurgler (2006). The former uses surveybased measures to capture the optimism (pessimism) of investors in weekly and monthly intervals. The latter is composed of macroeconomic variables and anomalies such as the closed-end fund discount, stock exchange share turnover, first-day returns on IPOs, the equity share in new issues, and the dividend premium. However, very few previous studies utilize a high-frequency investor sentiment proxy. To that effect, we follow the approach of Da et al. (2015) to generate an index of aggregate negative SVI for a list of 30 search terms previously identified as negatively correlated with the market. ${ }^{1}$ However, we expand the sample of the daily observations from 1 January 2004 to 31 December 2016. We then observe the effects of the FEARS investor sentiment measure on a set of ADR indices to assess its effect on the aggregate market of cross-listed securities.

There are two key benefits of using the SVI method to construct investor sentiment measures. First, we can test various hypotheses that can only be tested using daily data. This would not be possible using survey data, which is typically available on a weekly or monthly basis. Second, it allows us to measure the contemporaneous effects (and potential short-term reversals) of changes in U.S. households' opinions as measured by their internet search patterns. Moreover, this method reduces sampling biases such as those observed in survey-based studies (Singer 2002). It also mitigates the problem of using an indirect proxy of sentiment, like the one derived from macro variables and market anomalies such as the "top-down" approach used by Baker and Wurgler (2006), criticized by Qiu and Welch $(2004)^{2}$.

According to the World Bank (2020), the percentage of internet users in the U.S. in 2016 stood at $85.5 \%$. The use of internet search data represents a solid reason to consider this sentiment index as a reliable representation of the U.S. population's concerns and interests. In Figure 1, we show the SVI on Google Trends for the word "crisis" from January 2004 to December 2016.

This study contributes to the literature by examining the relationship between U.S. investor sentiment and foreign securities returns using high-frequency data. Similar to U.S. stock returns, the results show a negative contemporaneous relationship between the FEARS investor sentiment measure and the ADR aggregate market returns, followed by a positive reversal the following trading day. Furthermore, this paper provides evidence of the impact of SVI-derived sentiment measures on a cross-listed security index that, to our knowledge, has not been studied before. Results are consistent for equally-weighted and value-weighted ADR portfolios. Lastly, we show that U.S. investor sentiment impacts regional ADR indices differently. Latin American ADR indices exhibit almost twice the effect of that shown by European and Asian ADR indices. 


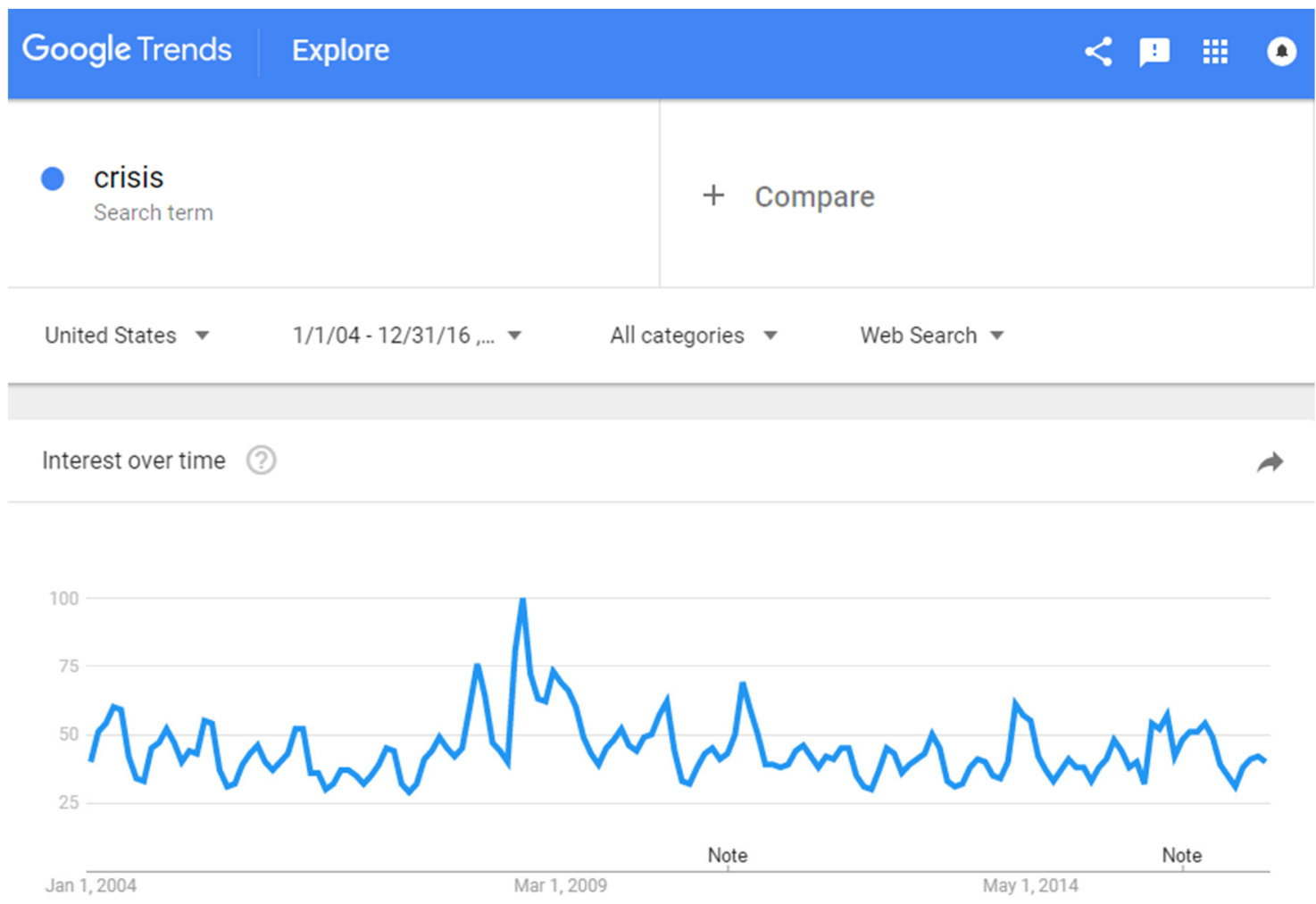

Figure 1. Sample of Search Volume Index (SVI) on Google for the word "crisis". Note: This figure presents the search volume index (SVI) for the search term "Crisis" from January 2004 to December 2016. Increases in SVI imply an increase in the search term "Crisis" in the United States according to Google Trends. Source: Google Trends (www.google.com/trends, accessed on 16 March 2018).

The remainder of this paper is organized as follows: Section 2 discusses the previous literature; Section 3 explains the data and methodology, including a detailed description of the construction of the index and its differences with the original FEARS proposed by Da et al. (2015); Section 4 presents the empirical results; Section 5 performs robustness tests, including the use of the original FEARS index; and Section 6 provides a conclusion to the study.

\section{Literature Review}

\subsection{FEARS}

In their paper, Da et al. (2015) developed the Financial and Economic Attitudes Revealed by Search (FEARS) by aggregating the Google search data on 30 search terms with a negative and economic categorization derived from the Harvard IV-4 dictionary. They found that increases in this negative sentiment have a same day negative effect on U.S. domestic stock returns followed by a next-day reversal effect. Gao et al. (2020) used a weekly measure of FEARS and found a negative effect on stock returns for 38 different countries from 2004-2014. Moreover, utilizing the FEARS to predict bitcoin returns, Burgraff et al. (2020) developed trading strategies that outperform buy-and-hold portfolios of cryptocurrencies. In addition, Kostopoulos et al. (2020) found that when FEARS is high, individual investors positioned themselves on the sell side of risky assets.

\subsection{SVI}

Search Volume Index (SVI) is a tool that allows for the quantification of the number of searches or queries performed by users of the internet on a search term for a specific search engine. The use of SVI data in the literature has been increasing at a rapid pace because it (often) offers an unbiased indicator of internet users' attention to a specific topic. The use of SVI data is becoming more prevalent in finance and economics studies. In this sense, 
using stock tickers, Da et al. (2011) found a positive relationship between SVIs and stock prices, with a subsequent price reversal within a year. Furthermore, Irresberger et al. (2015) were able to explain bank stock underperformance with SVI using terms such as "bank run" and "financial crisis."

Furthermore, Vozlyublennaia (2014) used Google Trends and found that a shock to stock returns causes a long-term change in investors' attention.

Similar to the SVI method, other studies have focused on using different internet sources of information to show the effects of investor sentiment on stock markets. For example, Siganos et al. (2014) used Facebook's Gross National Happiness Index to show how a positive stock return on Mondays came from increases in the overall good mood from Sundays. Moreover, Zhang et al. (2016) used a Twitter sentiment proxy to explain stock market performance in 11 countries.

\subsection{ADRs}

According to Jiang (1998), cross-listed securities have become a portfolio diversification tool that can provide a significant improvement of the risk-return trade-off in stock portfolios. These findings are consistent with the ones presented by Ely and Salehizadeh (2001). They found that ADRs are cointegrated with their underlying shares; therefore, long-term investors utilize them as substitutes for foreign stocks. However, when studying the fundamentals from both markets, the U.S. and the home country, they found both markets to be important sources of information for ADR stocks. Similarly, Peterburgsky and Yang (2013) found that investing in the underlying shares is more useful for diversification purposes than ADRs when U.S. stock market returns are low, and when the U.S. economy is underperforming. Moreover, Gagnon and Karolyi (2010) showed that even though the cross-listing of companies has slowed during the past few years, globalization has continued, suggesting that ADRs can still be considered an international market cointegration factor. Other studies have shown the price correction effect that exists for dually listed securities with extreme market values (Madura and Richie 2007).

Most of the ADR research that studies investor sentiment has focused on explaining the deviations from the price-parity condition between ADRs and their underlying securities; such deviations are commonly known as ADR mispricing (Suh 2003; Grossmann et al. 2007; Beckmann et al. 2015; Wu et al. 2017). For example, Hwang (2011) used countryspecific popularity among the U.S. population to explain the mispricing behind country closed-end funds (CCEFs) and ADRs. The results showed that stocks from more (less) popular countries are likely to exhibit a premium (discount) in their cross-listed securities. Perez-Liston et al. (2018) used a vector autoregressive approach to examine the spillover effect of U.S. investor sentiment on Mexican stock market returns and found that this effect is distinct from the domestic sentiment. Moreover, Verma and Soydemir (2006), using survey data, studied the effect of U.S. institutional investor sentiments on foreign stock markets. They determined that this effect has varying degrees of impact depending on the equity markets (U.K., Mexico, and Brazil, and no effect on Chile) and the type of sentiment used (institutional investor or individual investor sentiment). Using survey data, Bathia et al. (2016), contributed to the literature of U.S. sentiment spillover and found that aggregate market and growth stocks of all non-US G7 countries are significantly affected by the propagation of the U.S. market sentiment. However, to date, no other study has observed the contemporaneous effect of high-frequency investor sentiment on ADR returns. Furthermore, this is the first study that uses an SVI-driven sentiment on cross-listed security indices returns.

\section{Data and Methodology}

In this section, we discuss the data sources and methodology used in this study. Furthermore, we provide details on the construction of our investor sentiment measure. 


\subsection{The SVI Sentiment Index}

Google Trends provides information for Search Volume Indices (SVIs). These indices rank the relative search index popularity for each keyword used in their search engines on a scale from 0 to 100. Using SVIs to form an investor sentiment index, Da et al. (2015) showed that investor sentiment negatively impacts the returns of the S\&P 500 on the same trading day, followed by a positive reversal adjustment on the following day. This index is constructed by aggregating search queries of U.S. internet users for terms such as "inflation," "crisis", and "unemployment." The use of SVI follows a multidisciplinary trend in research that seeks to use aggregate internet search queries as a reflection of the public's interests and concerns.

Instead of using the text analytics literature to identify the words with economic meanings (e.g., Tetlock 2007; Tetlock et al. 2008), we started by collecting daily search volume indices for a set of 30 search terms, previously identified by Da et al. (2015), that report the largest negative correlation with the market ${ }^{3}$. Table 1 provides a list of the search terms used to construct the index.

Table 1. List of negative search terms.

\begin{tabular}{|c|c|}
\hline & Search Term \\
\hline 1 & Gold Prices \\
\hline 2 & Recession \\
\hline 3 & Gold Price \\
\hline 4 & Depression \\
\hline 5 & Great Depression \\
\hline 6 & Gold \\
\hline 7 & Economy \\
\hline 8 & Price Of Gold \\
\hline 9 & The Depression \\
\hline 10 & Crisis \\
\hline 11 & Frugal \\
\hline 12 & GDP \\
\hline 13 & Charity \\
\hline 14 & Bankruptcy \\
\hline 15 & Unemployment \\
\hline 16 & Inflation Rate \\
\hline 17 & Bankrupt \\
\hline 18 & The Great Depression \\
\hline 19 & Car Donate \\
\hline 20 & Capitalization \\
\hline 21 & Expense \\
\hline 22 & Donation \\
\hline 23 & Savings \\
\hline 24 & Social Security Card \\
\hline 25 & The Crisis \\
\hline 26 & Default \\
\hline 27 & Benefits \\
\hline 28 & Unemployed \\
\hline 29 & Poverty \\
\hline 30 & Social Security Office \\
\hline
\end{tabular}

Note: This table shows the 30 search terms reported by Da et al. (2015) to have the highest negative correlation with stock market returns for their entire sample. The terms are sorted from most negative to least negative, according to Da et al. (2015).

Using Google Trends (www.google.com/trends, accessed on 16 March 2018), we downloaded the daily search volume index for each search term from 1 January 2004 to 31 December 2016. Each index ranges between 0 and 100, depending on the number of searches for the specific word or term at a specific time. Therefore, if investors are pessimistic about the performance of the stock market, the aggregate search for these negative economic search terms increases. In Figure 1, we observe a spike in the SVI for 
the search term "crisis." It reaches a value of 100 during the 2008 financial crisis. However, given that our period of analysis also includes times of relative economic growth, we encountered some negative search terms that have values of " 0 " for an important number of periods (i.e., Google Trends does not report positive observations for the term "Car Donate" in the first quarter of 2010).

Google Trends allows users to filter the results by their geographic location of the query. Since our main interest is U.S. household search historical information, we restricted the results to show only those from U.S. internet users. After compiling the observations for each search term, we proceeded to calculate the daily change in search term $j$ as:

$$
\Delta S V I_{j, t}=\ln \left(S V I_{j, t}\right)-\ln \left(S V I_{j, t-1}\right)
$$

Each search term presents normality concerns that have to be addressed before continuing. Therefore, we applied the same methods as Da et al. (2015) to deseasonalize, winsorize, and standardize each series, and then calculated the average to obtain our index:

$$
\text { NewFEARS } S_{t}=\frac{1}{30} \times \sum_{j=1}^{30} \Delta S V I_{j t}
$$

\subsection{Additional Data}

We collected daily data from various sources to proceed with our study. We downloaded the Bank of New York Mellon ADR index andF ${ }^{4}$ regional ADR indices for Asia, Europe, and Latin America. The Trade Weighted U.S. Dollar Index: Broad [DTWEXB], is retrieved from FRED, Federal Reserve Bank of St. Louis. ${ }^{5}$ We constructed equally- and value-weighted ADR portfolios using all available ADRs from CRSP from July 2004 to December 2015.

One benefit of using ADR indices instead of individual stocks is to prevent illiquid securities from skewing the results of our research, as explained by Hwang (2011), who found that securities from more popular countries exhibit a higher turnover. Additionally, the Bank of New York Mellon ADR indices are used as a reference in the industry for Exchanged Traded Funds (ETFs). ${ }^{6}$ Kabir et al. (2011) found that there exists a substitutability effect of investing in ADRs and their respective country indices.

Additionally, we retrieved the Chicago Board Options Exchange (CBOE) daily market volatility index (VIX) directly from the CBOE website ${ }^{7}$. The VIX measures the implied volatility of stock options trading in the S\&P 500, also commonly known as the "investor fear index ${ }^{8}$. This measure is widely used in the literature as a proxy for investor sentiment (Baker and Wurgler 2007). To include a high-frequency measure for macroeconomic activity, we collected the Aruoba-Diebold-Scotti (ADS) 9 index from the Federal Reserve Bank of Philadelphia. ADS is a seasonally-adjusted index that encompasses a series of economic indicators such as weekly initial jobless claims, monthly payroll employment, industrial production, personal income less transfer payments, manufacturing and trade sales, and quarterly real GDP. The average value of the ADS is zero. For example, during the 2007-2008 crisis, the index dropped to its lowest negative value of -4.0 , while a value of positive 1.0 was achieved in early 2010 . Including this variable in the model will control for macroeconomic conditions that influence financial markets.

To measure economic policy uncertainty (EPU), we obtained an index developed by Baker et al. $(2015)^{10}$. This index has three components; the first component quantifies newspaper coverage of policy-related economic uncertainty, the second component reflects the number of federal tax code provisions set to expire in future years, and the third component uses disagreement among economic forecasters as a proxy for uncertainty. We include this variable to control for the negative sentiment that policymakers and financial analysts could introduce into markets with their announcements in the news, ultimately, affecting the mainstream public opinion that feeds a climate of uncertainty. 
As a last step, we downloaded the original daily FEARS index used by Da et al. (2015) from Professor Joseph Engelberg's website (Engelbert). The index ranges from 1 July 2004 to 30 December 2011. The construction of their index differs slightly from the one we estimate in this study. They identified 30 search terms with the highest $t$-statistic values during 6-month periods by using expanding rolling regressions from a larger list of 118 search terms. However, in their study, they only reported the 30 search terms with the highest $t$-statistic values over their entire sample period. We used these 30 search terms to construct our sentiment measure ${ }^{11}$.

\section{Results}

\subsection{New FEARS and ADR Returns}

To estimate the marginal effect of the New FEARS index on ADR returns, we estimate the following regression model:

$$
\text { return }_{i, t+k}=\beta_{0}+\beta_{1} \text { NewFEARS }+\sum_{m} \gamma_{m} \text { Control }_{i, t}^{m}+u_{i, t}
$$

where $\operatorname{return}_{i, t+k}$ is the index $i$ 's return on day $t+k$. To evaluate the two day cumulative

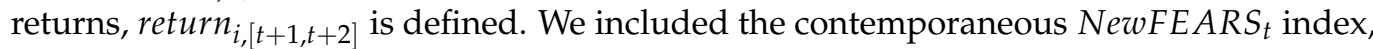
which is the main variable of interest in this study. Consistent with previous studies (Da et al. 2015), we expected a negative sign for the $\beta_{1}$ coefficient for the same-day returns and a positive coefficient for the following day's returns $(k>0 ; k=2)$. Although ADRs represent shares from companies originally listed abroad, they are traded in the U.S. and therefore subject to changes in American investors' expectations. A vector of control variables, Control $l_{i, t}^{m}$, includes up to five lags of the index or portfolio returns, changes in economic policy uncertainty $(\triangle \mathrm{EPU})$, changes in macroeconomic factors ( $\triangle \mathrm{ADS})$, the daily values of the CBOE volatility index (VIX), and changes in the exchange rate. We used the changes in the exchange rate for a basket of U.S. trade-weighted ( $\triangle$ FX U.S. T-W) currencies when estimating the general ADR index returns. The country-specific exchange rate versus the U.S. dollar is only used when we estimated the regressions for country-specific ADR indices. Following Tetlock (2007) and Da et al. (2015), we included five (5) days of lagged returns in the model. However, after testing for different specifications, we observed that the results are qualitatively the same, regardless of the number of lags included.

Table 2 displays the summary statistics for the main variables used in this study. The ADR index exhibits a slightly positive mean. On an annual basis, the average ADR index returns are $3.8 \%$ compared to $6.9 \%$ for the S\&P $500^{12}$. P The mean for the New FEARS index is 0 ; this is to be expected given the construction of this variable. Changes in ADS have an average close to zero; this suggests that over the time of our study, economic conditions have been both equally positive and negative. Moreover, the U.S. trade-weighted currency index has an average change of 0.0033 , which suggests a small appreciation of the U.S. dollar $(0.84 \%$ on an annualized basis) compared to its major trading partners.

Table 3 reports the baseline regressions using the general BNY ADR index returns as the dependent variable. The New FEARS coefficient $(-0.323)$ is negative and statistically significant at the $1 \%$ level. This means that when the aggregate index of negative (e.g., depression, recession) search terms increases, ADR stock prices decrease, causing a contemporaneous negative return. Although the coefficients on the New FEARS index are negative and significant, they are of a smaller magnitude than those reported by Da et al. (2015). However, in the robustness section, we match the sample of their study, and the results are qualitatively the same ${ }^{13}$. In Model 1, a one standard deviation increase in the New FEARS index (0.3906) represents a 13-basis point decrease in ADR returns. We do not observe a significant reversal effect on the next day $(t+1)$ returns (column 2$)$, the second day after $(t+2)$ (column 3), nor the cumulation of both (column 4) as reported by Da et al. (2015). In Models 5, 6, and 7 we estimate the model with additional control variables. We include changes in the trade-weighted U.S. dollar exchange rate to control for changes in the U.S. dollar, remove the lagged returns, and changes in EPU and ADS. As expected, the 
coefficient for the New FEARS index remains negative and statistically significant across all specifications. Moreover, not surprisingly, the coefficient for the changes in the U.S. currency against a basket of trade-weighted currencies is negative and significant, which means that when the dollar appreciates with respect to other currencies, ADR returns decrease. The inclusion of the exchange rate increases the explanatory power of the model from $3.5 \%$ to $16.2 \%$, suggesting that it is an important control variable.

Table 2. Summary statistics.

\begin{tabular}{cccccc}
\hline Variable & Obs. & Mean & Std. Dev. & Min. & Max. \\
\hline BNY ADR Index Returns & 3273 & 0.0151 & 1.4410 & -11.2691 & 15.3246 \\
New FEARS & 3273 & 0.0000 & 0.3906 & -2.1508 & 2.0320 \\
FEARS & 1891 & 0.0000 & 0.3548 & -2.54975 & 3.1864 \\
VIX & 3273 & 19.1041 & 9.0850 & 9.8900 & 80.8600 \\
AEPU & 3273 & -4.9097 & 54.4314 & -303.5500 & 393.6700 \\
AADS & 3273 & 0.0001 & 0.0142 & -0.0708 & 0.0846 \\
$\Delta$ FX U.S. T-W & 3246 & 0.0033 & 0.3929 & -3.3854 & 2.3692 \\
EW ADR Returns & 2707 & 0.5859 & 1.4185 & -9.3038 & 14.4993 \\
VW ADR Returns & 2707 & 0.4167 & 1.4492 & -10.9089 & 15.0293 \\
\hline
\end{tabular}

Notes: This table reports summary statistics for the main variables used in this study. ADR Index returns are the single day returns for the BNY Mellon ADR Index. New FEARS is the main sentiment measure of interest. FEARS is the original index used by Da et al. (2015), collected from Dr. Engelberg's website. The VIX is the implied volatility of the S\&P 500 index, calculated by the Chicago Board of Exchange. $\triangle E P U$ is the change in the Economic Policy Uncertainty index, $\triangle$ ADS represents the changes in the Arouba-Diebold-Scotti business conditions index, the $\triangle F X$ U.S. T-W denotes the changes in the exchange rate between the U.S. dollar and a basket of trade-weighted currencies, EW ADR returns represent the returns of an equally-weighted portfolio of ADRs, and VW ADR returns represent the returns of a value-weighted portfolio of ADRs. Most daily data were collected from 1 January 2004 through 31 December 2016, except for the EW and VW ADR returns which were only available from 1 July 2004 to 31 March 2015.

Table 3. New FEARS and ADR index returns.

\begin{tabular}{|c|c|c|c|c|c|c|c|}
\hline \multirow{3}{*}{$\begin{array}{c}\text { Independent } \\
\text { Variables }\end{array}$} & \multicolumn{7}{|c|}{ Dependent Variable: BNY ADR Index Returns } \\
\hline & (1) & (2) & (3) & $(4)$ & (5) & (6) & (7) \\
\hline & $\operatorname{Ret}(t)$ & $\operatorname{Ret}(t+1)$ & Ret $(t+2)$ & $\operatorname{Ret}[t+1, t+2]$ & $\operatorname{Ret}(t)$ & $\operatorname{Ret}(t)$ & $\operatorname{Ret}(t)$ \\
\hline \multirow{2}{*}{ New FEARS } & $-0.3230 * * *$ & -0.0110 & 0.0231 & 0.0120 & $-0.3160 * * *$ & $-0.2590 * * *$ & $-0.2860 * * *$ \\
\hline & $(0.0879)$ & $(0.0631)$ & $(0.0724)$ & $(0.0843)$ & $(0.0829)$ & $(0.0768)$ & $(0.0668)$ \\
\hline \multirow[t]{2}{*}{ VIX } & $-0.0216^{* * *}$ & 0.0040 & 0.0027 & 0.0067 & $-0.0217 * *$ & $-0.0180^{* *}$ & $0.0215^{* * *}$ \\
\hline & $(0.0070)$ & $(0.0051)$ & $(0.0065)$ & $(0.0091)$ & $(0.0084)$ & $(0.0073)$ & $(0.0062)$ \\
\hline \multirow[t]{2}{*}{$\triangle \mathrm{EPU}$} & 0.00003 & $-0.0011 *$ & $0.0012 *$ & 0.0001 & & 0.0003 & 0.0001 \\
\hline & $(0.0008)$ & $(0.0006)$ & $(0.0006)$ & $(0.0008)$ & & $(0.0006)$ & $(0.0006)$ \\
\hline \multirow[t]{2}{*}{$\triangle \mathrm{ADS}$} & -3.5660 & -2.8640 & -2.8280 & -5.6910 & & -3.3130 & -3.6850 \\
\hline & $(2.5670)$ & $(3.1260)$ & $(2.6710)$ & $(4.7400)$ & & $(2.8890)$ & $(2.4530)$ \\
\hline \multirow[t]{2}{*}{$\operatorname{Ret}(t)$} & & $-0.0703^{* *}$ & -0.0477 & $-0.1180^{* *}$ & & & \\
\hline & & $(0.0322)$ & $(0.0451)$ & $(0.0570)$ & & & \\
\hline \multirow[t]{2}{*}{$\operatorname{Ret}(t-1)$} & $-0.0922^{* * *}$ & $-0.0539 *$ & 0.0007 & -0.0532 & $-0.0913^{* * *}$ & & $-0.1430^{* * *}$ \\
\hline & $(0.0314)$ & $(0.0299)$ & $(0.0325)$ & $(0.0475)$ & $(0.0325)$ & & $(0.0284)$ \\
\hline \multirow[t]{2}{*}{$\operatorname{Ret}(t-2)$} & -0.0691 & -0.0118 & -0.0035 & -0.0153 & $-0.0684^{*}$ & & -0.0496 \\
\hline & $(0.0448)$ & $(0.0370)$ & $(0.0367)$ & $(0.0463)$ & $(0.0366)$ & & $(0.0350)$ \\
\hline \multirow[t]{2}{*}{$\operatorname{Ret}(t-3)$} & -0.0250 & -0.0115 & -0.0374 & -0.0489 & -0.0244 & & -0.0171 \\
\hline & $(0.0356)$ & $(0.0345)$ & $(0.0445)$ & $(0.0437)$ & $(0.0354)$ & & $(0.0302)$ \\
\hline \multirow[t]{2}{*}{$\operatorname{Ret}(t-4)$} & -0.0228 & -0.0543 & 0.0050 & -0.0492 & -0.0224 & & -0.0223 \\
\hline & $(0.0361)$ & $(0.0433)$ & $(0.0404)$ & $(0.0456)$ & $(0.0335)$ & & $(0.0331)$ \\
\hline \multirow[t]{2}{*}{$\operatorname{Ret}(t-5)$} & -0.0595 & -0.0155 & -0.0232 & -0.0386 & -0.0588 & & -0.0391 \\
\hline & $(0.0439)$ & $(0.0396)$ & $(0.0436)$ & $(0.0582)$ & $(0.0457)$ & & $(0.0396)$ \\
\hline \multirow[t]{2}{*}{$\Delta$ FX U.S. T-W } & & & & & & $-1.2580^{* * *}$ & $-1.3360^{* * *}$ \\
\hline & & & & & & (0.0957) & (0.0923) \\
\hline \multirow[t]{2}{*}{ Constant } & $0.4410^{* * *}$ & -0.0652 & -0.0265 & -0.0918 & $0.4420 * * *$ & $0.3680^{* * *}$ & $0.4390^{* * *}$ \\
\hline & $(0.1210)$ & $(0.0937)$ & $(0.1080)$ & $(0.1600)$ & $(0.1430)$ & $(0.1310)$ & $(0.1020)$ \\
\hline Observations & 3268 & 3267 & 3266 & 3266 & 3268 & 3246 & 3241 \\
\hline$R$-squared & 0.035 & 0.014 & 0.007 & 0.015 & 0.033 & 0.140 & 0.162 \\
\hline
\end{tabular}

Notes: This table regresses the BNY ADR Index daily returns to the New FEARS and a set of control variables for the time period from 1 January 2004 to 30 December 2016. The dependent variable is the contemporaneous returns for the BNY Mellon ADR Index. The independent variable is the New FEARS index and a set of control variables, which includes the implied volatility of the S\&P 500 (VIX) index, the changes in the Economic Public Uncertainty ( $\triangle E P U)$ index, the changes in the Arouba-Diebold-Scotti business conditions index ( $\triangle \mathrm{ADS}$ ), lagged returns (up to five lags), and the changes in the exchange rate between the U.S. dollar and a basket of trade-weighted currencies ( $\triangle$ FX U.S. T-W). The standard errors are bootstrapped and displayed in parentheses. ${ }^{*}, * *$, and ${ }^{* * *}$ denote significance at the $10 \%$, $5 \%$, and $1 \%$ levels, respectively. 
Next, we constructed equally and value-weighted portfolios with all ADRs available from CRSP and calculated the returns for the period beginning 1 July 2004 and ending 31 March 2015. We used the same regression model (1) and reported the results in Table 4. The results are consistent with those previously obtained in Table 3 for both portfolios. The New FEARS index coefficient is both negative and statistically significant at the $1 \%$ level for all contemporaneous $(t$ ) returns (columns 1, 5, 6, and 10). Moreover, we observe a reversal effect on next day $(t+1)$ returns, the coefficients are (columns 2 and 7 ) positive and significant at the $10 \%$ level. This means that increases in the New FEARS index have a negative same-day effect but quickly reverse by almost half the next trading day. An interesting finding is that the New FEARS coefficients are almost twice the size found in the BNY ADR index returns. A unit increase in the standard deviation of the New FEARS sentiment index represents a drop of almost 26 basis points for the equallyweighted portfolio and 23 basis points in the returns for the value-weighted portfolio. This slight difference between the coefficients of equally-weighted and value-weighted portfolios suggests that lower market capitalization ADRs are more affected than high market capitalization ADRs. This is consistent with the ADR mispricing evidence shown in previous studies (Beckmann et al. 2015).

Table 4. New FEARS and equally-weighted and value-weighted ADR portfolio returns.

\begin{tabular}{|c|c|c|c|c|c|c|c|c|c|c|}
\hline \multirow{3}{*}{$\begin{array}{l}\text { Independent } \\
\text { Variables }\end{array}$} & \multicolumn{5}{|c|}{ Dependent Variable: ADR Equally-Weighted Portfolio Returns } & \multicolumn{5}{|c|}{ Dependent Variable: ADR Value-Weighted Portfolio Returns } \\
\hline & (1) & (2) & (3) & (4) & (5) & (6) & (7) & (8) & (9) & (10) \\
\hline & Ret $(t)$ & Ret $(t+1)$ & Ret $(t+2)$ & $\operatorname{Ret}[t+1, t+2]$ & $\operatorname{Ret}(t)$ & $\operatorname{Ret}(t)$ & $\operatorname{Ret}(t+1)$ & Ret $(t+2)$ & $\operatorname{Ret}[t+1, t+2]$ & $\operatorname{Ret}(t)$ \\
\hline New FEARS & $\begin{array}{c}-0.6610^{* * *} \\
(0.1790)\end{array}$ & $\begin{array}{l}0.2890 * \\
(0.1570)\end{array}$ & $\begin{array}{l}-0.0637 \\
(0.1360)\end{array}$ & $\begin{array}{c}0.2810 \\
(0.2009)\end{array}$ & $\begin{array}{c}-0.6520 * * * \\
(0.1370)\end{array}$ & $\begin{array}{c}-0.5960^{* * *} \\
(0.1620)\end{array}$ & $\begin{array}{l}0.2600 * \\
(0.1430)\end{array}$ & $\begin{array}{l}-0.1020 \\
(0.1260)\end{array}$ & $\begin{array}{c}0.1860 \\
(0.1740)\end{array}$ & $\begin{array}{c}-0.5880 \text { *** } \\
(0.1260)\end{array}$ \\
\hline VIX & $\begin{array}{c}-0.0163^{* *} \\
(0.0080)\end{array}$ & $\begin{array}{c}0.0048 \\
(0.0069)\end{array}$ & $\begin{array}{c}0.0016 \\
(0.0080)\end{array}$ & $\begin{array}{l}0.0067 \\
(0.012)\end{array}$ & $\begin{array}{c}-0.0159 * * * \\
(0.0061)\end{array}$ & $\begin{array}{c}-0.0182 \text { ** } \\
(0.0076)\end{array}$ & $\begin{array}{c}0.0036 \\
(0.0095)\end{array}$ & $\begin{array}{l}-0.0001 \\
(0.0078)\end{array}$ & $\begin{array}{c}0.0042 \\
(0.0111)\end{array}$ & $\begin{array}{c}-0.0182^{* * *} \\
(0.0060)\end{array}$ \\
\hline$\triangle \mathrm{EPU}$ & $\begin{array}{c}0.0003 \\
(0.0008)\end{array}$ & $\begin{array}{l}-0.0006 \\
(0.0008)\end{array}$ & $\begin{array}{c}0.0021 * * * \\
(0.0008)\end{array}$ & $\begin{array}{l}0.0021 * \\
(0.0011)\end{array}$ & $\begin{array}{c}0.0001 \\
(0.0007)\end{array}$ & $\begin{array}{c}0.0004 \\
(0.0009)\end{array}$ & $\begin{array}{l}-0.0009 \\
(0.0008)\end{array}$ & $\begin{array}{l}0.0020^{* *} \\
(0.0009)\end{array}$ & $\begin{array}{l}0.0016^{*} \\
(0.0009)\end{array}$ & $\begin{array}{c}0.0001 \\
(0.0007)\end{array}$ \\
\hline$\triangle \mathrm{ADS}$ & $\begin{array}{l}-4.0180 \\
(3.5290)\end{array}$ & $\begin{array}{l}-4.1920 \\
(3.7960)\end{array}$ & $\begin{array}{l}-4.8930 \\
(3.5750)\end{array}$ & $\begin{array}{l}-8.9680 \\
(5.7370)\end{array}$ & $\begin{array}{l}-3.8640 \\
(2.9990)\end{array}$ & $\begin{array}{l}-5.0110 * \\
(3.0390)\end{array}$ & $\begin{array}{l}-5.2430 \\
(3.9030)\end{array}$ & $\begin{array}{l}-4.8770 \\
(3.1740)\end{array}$ & $\begin{array}{c}-10.4300 * * \\
(5.1480)\end{array}$ & $\begin{array}{c}-4.8020 * * \\
(2.3380)\end{array}$ \\
\hline $\operatorname{Ret}(t)$ & & $\begin{array}{l}0.02780 \\
(0.0382)\end{array}$ & $\begin{array}{l}-0.0026 \\
(0.0434)\end{array}$ & $\begin{array}{c}0.0230 \\
(0.0658)\end{array}$ & & & $\begin{array}{l}-0.0492 \\
(0.0397)\end{array}$ & $\begin{array}{l}-0.0596 \\
(0.0497)\end{array}$ & $\begin{array}{l}-0.110 * \\
(0.0623)\end{array}$ & \\
\hline $\operatorname{Ret}(t-1)$ & $\begin{array}{l}-0.0016 \\
(0.0425)\end{array}$ & $\begin{array}{l}-0.0005 \\
(0.0516)\end{array}$ & $\begin{array}{c}0.0022 \\
(0.0393)\end{array}$ & $\begin{array}{l}-0.0098 \\
(0.0702)\end{array}$ & $\begin{array}{c}-0.0680 * * \\
(0.0312)\end{array}$ & $\begin{array}{c}-0.0782 \text { ** } \\
(0.0365)\end{array}$ & $\begin{array}{l}-0.0584 \\
(0.0496)\end{array}$ & $\begin{array}{l}-0.0100 \\
(0.0414)\end{array}$ & $\begin{array}{l}-0.0777 \\
(0.0745)\end{array}$ & $\begin{array}{c}-0.1540 * * * \\
(0.0264)\end{array}$ \\
\hline$\Delta$ FX U.S. T-W & & & & & $\begin{array}{c}-1.4320 * * * \\
(0.1130)\end{array}$ & & & & & $\begin{array}{c}-1.4940^{* * *} \\
(0.1290)\end{array}$ \\
\hline Constant & $\begin{array}{c}0.3630 * * * \\
(0.1400)\end{array}$ & $\begin{array}{l}-0.0447 \\
(0.1220)\end{array}$ & $\begin{array}{c}0.0230 \\
(0.1340)\end{array}$ & $\begin{array}{l}-0.0309 \\
(0.2120)\end{array}$ & $\begin{array}{c}0.3540 * * * \\
(0.1080)\end{array}$ & $\begin{array}{c}0.4010 * * * \\
(0.1310)\end{array}$ & $\begin{array}{l}-0.0220 \\
(0.1590)\end{array}$ & $\begin{array}{c}0.0512 \\
(0.1340)\end{array}$ & $\begin{array}{c}0.0144 \\
(0.1970)\end{array}$ & $\begin{array}{c}0.4020^{* * *} \\
(0.1020)\end{array}$ \\
\hline Observations & 2233 & 2146 & 2144 & 2059 & 2211 & 2233 & 2146 & 2144 & 2059 & 2211 \\
\hline$R$-squared & 0.031 & 0.007 & 0.010 & 0.010 & 0.173 & 0.037 & 0.014 & 0.011 & 0.019 & 0.181 \\
\hline
\end{tabular}

Notes: This table reports the equally-weighted (EW) and value-weighted (VW) ADR portfolio daily returns regressed on the New FEARS index and a set of control variables for the time period from 1 July 2004 to 31 March 2015. The dependent variables in columns 1 and 2 are the contemporaneous returns. The independent variables are the New FEARS index and a set of control variables, including the implied volatility of the S\&P 500 (VIX) index, the changes in the Economic Public Uncertainty ( $\triangle \mathrm{EPU})$ index, the changes in the Arouba-Diebold-Scotti business conditions index ( $\triangle$ ADS), lagged returns up to five lags (only lags at time $t$ and $t-1$ are reported, others are available upon request), and the changes in the exchange rate between the U.S. dollar and a basket of trade-weighted currencies ( $\Delta$ FX U.S. $\mathrm{T}-\mathrm{W})$. The standard errors are bootstrapped and displayed in parentheses. ${ }^{*}, * *$, and ${ }^{* * *}$ denote significance at the $10 \%, 5 \%$, and $1 \%$ levels, respectively.

\subsection{New FEARS and ADR Regional Index Returns}

This section presents the results for the effect of the New FEARS index on ADR indices by regional cross-listed securities. Table 5 shows the negative effect of the New FEARS Index on contemporaneous returns for Asia, Europe, and Latin America. Interestingly, the coefficients for Latin American ADR returns are almost twice that of the observed coefficients for Asian and European indices. In models for Asia (1), Europe (2), and Latina America (3), a standard deviation increase in New FEARS corresponds to a decrease of 12,11 , and 22 basis points, respectively. The coefficients remain similar when we include changes in dollar appreciation with respect to its trade partners as shown in models for Asia (4), Europe (5), and Latina America (6). A standard deviation increase in New FEARS corresponds to a decrease of 10,9 , and 20 basis points, respectively. 
Table 5. New FEARS and ADR regional indices.

\begin{tabular}{|c|c|c|c|c|c|c|}
\hline \multirow{3}{*}{$\begin{array}{c}\text { Independent } \\
\text { Variables }\end{array}$} & \multicolumn{6}{|c|}{ Dependent Variable: Regional ADR Returns } \\
\hline & (1) & (2) & (3) & (4) & (5) & (6) \\
\hline & Asia & Europe & Latin America & Asia & Europe & Latin America \\
\hline New FEARS & $\begin{array}{c}-0.3060 * * * \\
(0.0835)\end{array}$ & $\begin{array}{c}-0.2880^{* * *} \\
(0.0958)\end{array}$ & $\begin{array}{c}-0.5710^{* * *} \\
(0.1100)\end{array}$ & $\begin{array}{c}-0.2640^{* * *} \\
(0.0877)\end{array}$ & $\begin{array}{c}-0.2410^{* * *} \\
(0.0633)\end{array}$ & $\begin{array}{c}-0.5090^{* * *} \\
(0.1200)\end{array}$ \\
\hline$\Delta$ FX U.S. T-W & & & & $\begin{array}{c}-0.9430 * * * \\
(0.0887)\end{array}$ & $\begin{array}{c}-1.3640^{* * *} \\
(0.0967)\end{array}$ & $\begin{array}{c}-1.4500^{* * *} \\
(0.1360)\end{array}$ \\
\hline VIX & $\begin{array}{c}-0.0173^{* *} \\
(0.0076)\end{array}$ & $\begin{array}{c}-0.0185^{* * *} \\
(0.0070)\end{array}$ & $\begin{array}{c}-0.0193 * \\
(0.0116)\end{array}$ & $\begin{array}{c}-0.0176^{* * *} \\
(0.0067)\end{array}$ & $\begin{array}{c}-0.0182^{* * *} \\
(0.0064)\end{array}$ & $\begin{array}{c}-0.0203^{* *} \\
(0.0096)\end{array}$ \\
\hline$\triangle \mathrm{EPU}$ & $\begin{array}{c}0.0002 \\
(0.0008)\end{array}$ & $\begin{array}{c}0.0001 \\
(0.0008)\end{array}$ & $\begin{array}{c}0.0007 \\
(0.0010)\end{array}$ & $\begin{array}{c}0.0004 \\
(0.0006)\end{array}$ & $\begin{array}{c}0.0002 \\
(0.0006)\end{array}$ & $\begin{array}{c}0.0010 \\
(0.0008)\end{array}$ \\
\hline$\triangle \mathrm{ADS}$ & $\begin{array}{l}-3.3210 \\
(2.6700)\end{array}$ & $\begin{array}{l}-2.7650 \\
(2.4970)\end{array}$ & $\begin{array}{l}-5.6640 \\
(3.6020)\end{array}$ & $\begin{array}{l}-3.8790 \\
(2.9260)\end{array}$ & $\begin{array}{l}-2.8000 \\
(2.3710)\end{array}$ & $\begin{array}{l}-6.1770 \\
(3.8430)\end{array}$ \\
\hline Constant & $\begin{array}{c}0.3610^{* * * *} \\
(0.1340)\end{array}$ & $\begin{array}{c}0.3760 * * * \\
(0.1170)\end{array}$ & $\begin{array}{c}0.4330 * * \\
(0.1990)\end{array}$ & $\begin{array}{c}0.3670^{* * *} \\
(0.1190)\end{array}$ & $\begin{array}{c}0.3690^{* * *} \\
(0.1090)\end{array}$ & $\begin{array}{c}0.4490^{* * *} \\
(0.1650)\end{array}$ \\
\hline Observations & 3273 & 3273 & 3273 & 3246 & 3246 & 3246 \\
\hline$R$-squared & 0.017 & 0.019 & 0.018 & 0.081 & 0.159 & 0.097 \\
\hline
\end{tabular}

Notes: This table reports the regression results for the regional ADR indices on the New FEARS index and a set of control variables for the time period from 1 January 2004 to 30 December 2016. The dependent variable in columns 1 and 4 is the Asia ADR index daily returns, in columns 2 and 5 the Europe ADR index daily returns, and in columns 3 and 6 the Latin America ADR index daily returns. The independent variable is the New FEARS index and a set of control variables including the implied volatility of the S\&P 500 (VIX) index, the changes in the Economic Public Uncertainty $(\triangle \mathrm{EPU})$ index, the changes in the Arouba-Diebold-Scotti business conditions index ( $\triangle \mathrm{ADS})$, and the changes in the exchange rate between the U.S. dollar and a basket of trade-weighted currencies ( $\Delta$ FX U.S. T-W). The standard errors are bootstrapped and displayed in parentheses. ${ }^{*}, * *$, and ${ }^{* * *}$ denote significance at the $10 \%, 5 \%$, and $1 \%$ levels, respectively.

These findings show that Latin American ADRs have a higher level of sensitivity to waves of negative U.S. investor sentiment. This is consistent with the findings of Verma and Soydemir (2006) who studied the effect of U.S. sentiment on Latin American and European countries, as well as the ones shown by Perez-Liston et al. (2018), who found that there exists a spillover effect between U.S. investor sentiment and Mexican stock returns. Another alternative explanation could be a higher correlation between the U.S markets and Latin American markets returns, as shown by Schaub (2013), who found that Latin American ADR's buy and hold returns are roughly the same as the S\&P 500 index.

\section{Robustness Tests}

To construct the New FEARS index we followed the steps of Da et al. (2015), with some minor but potentially significant modifications. We only used the top 30 negative search terms (e.g., recession, crisis) reported in their paper with the highest negative correlation. In their version of the FEARS, Da et al. (2015) used an expanding rolling regression of 118 (unreported) search terms to identify which 30 are the most significant in 6-month rolling windows. Moreover, they evaluated a shorter time period than our study (2004-2011). Although the methodology is similar, we suspect that the statistical power of the original index could be superior, since it refreshes its constituents to the most negative SVIs in six-month intervals. Nevertheless, in Table 6, we estimate the effect of the original FEARS on the BNY ADR index returns and observe that the effect is consistent with our previous findings; with the only difference being that a standard deviation change in the FEARS (0.3548) accounts for approximately 21 basis points in the ADR index contemporaneous returns. Moreover, we observe a positive and statistically significant next day reversal in the returns on $t+1$, and the cumulation of $t+1$ and $t+2$, meaning that an increase in negative sentiment today negatively affects ADR returns the same day, but positively affects the returns the following day. We also modeled our New FEARS for the same time period as the original FEARS, and the coefficient increases from the one observed in Table 3, suggesting that this sentiment has a greater impact during times of economic and financial turmoil. 
Table 6. FEARS and the BNY ADR Index.

\begin{tabular}{|c|c|c|c|c|c|c|c|c|c|c|}
\hline \multirow{4}{*}{$\begin{array}{l}\text { Independent } \\
\text { Variables }\end{array}$} & \multicolumn{5}{|c|}{ Dependent Variable: BNY ADR Index Returns } & & & & & \\
\hline & \multicolumn{5}{|c|}{ Original FEARS } & \multicolumn{5}{|c|}{ New FEARS } \\
\hline & (1) & (2) & (3) & (4) & (5) & (6) & (7) & (8) & (9) & (10) \\
\hline & Ret $(t)$ & Ret $(t+1)$ & Ret $(t+2)$ & $\operatorname{Ret}[t+1, t+2]$ & Ret $(t)$ & Ret $(t)$ & Ret $(t+1)$ & Ret $(t+2)$ & $\operatorname{Ret}[t+1, t+2]$ & Ret $(t)$ \\
\hline FEARS & $\begin{array}{c}-0.5830 * * * \\
(0.1640)\end{array}$ & $\begin{array}{l}0.2500 * \\
(0.1320)\end{array}$ & $\begin{array}{c}0.1700 \\
(0.1170)\end{array}$ & $\begin{array}{c}0.4200 * * \\
(0.1660)\end{array}$ & $\begin{array}{c}-0.4780 \\
* * * \\
(0.1670)\end{array}$ & & & & & \\
\hline New FEARS & & & & & & $\begin{array}{c}-0.4630 \\
* * * \\
(0.1380)\end{array}$ & $\begin{array}{c}0.0927 \\
(0.1090)\end{array}$ & $\begin{array}{c}0.0082 \\
(0.1090)\end{array}$ & $\begin{array}{c}0.1010 \\
(0.1550)\end{array}$ & $\begin{array}{c}-0.4690 \\
* * * \\
(0.1400)\end{array}$ \\
\hline VIX & $-0.0215^{* * *}$ & 0.0026 & 0.0014 & 0.0041 & $-\underset{* * *}{0.0198}$ & $-0.0207^{* *}$ & 0.0024 & 0.0014 & 0.0039 & -0.0190 \\
\hline$\triangle \mathrm{ADS}$ & $\begin{array}{l}(0.0079) \\
0.00003 \\
(0.0010) \\
-3.6740 \\
(4.8040)\end{array}$ & $\begin{array}{c}(0.0089) \\
-0.0017 \\
(0.0009) \\
-3.0260 \\
(4.1640)\end{array}$ & $\begin{array}{l}(0.0075) \\
0.0017 * * \\
(0.0007) \\
-3.0930 \\
(3.7570)\end{array}$ & $\begin{array}{l}(0.0116) \\
-0.00003 \\
(0.0011) \\
-6.1190 \\
(4.9170)\end{array}$ & $\begin{array}{l}(0.0061) \\
-0.0001 \\
(0.0008) \\
-3.5890 \\
(2.8700)\end{array}$ & $\begin{array}{c}(0.0084) \\
0.0001 \\
(0.0009) \\
-3.8580 \\
(3.4850)\end{array}$ & $\begin{array}{c}(0.0077) \\
-0.0018^{*} \\
(0.0010) \\
-3.0610 \\
(3.7360)\end{array}$ & $\begin{array}{l}(0.0080) \\
0.0017^{*} \\
(0.0010) \\
-3.1700 \\
(3.1940)\end{array}$ & $\begin{array}{l}(0.0096) \\
-0.0001 \\
(0.0012) \\
-6.2310 \\
(5.5000)\end{array}$ & $\begin{array}{l}(0.0060) \\
-0.0001 \\
(0.0008) \\
-3.8400 \\
(3.5190)\end{array}$ \\
\hline$\underset{\text { T-W }}{\Delta \mathrm{FX} \text { U.S. }}$ & & & & & $\begin{array}{l}-1.7370 \\
* * * \\
(0.1110)\end{array}$ & & & & & $\begin{array}{c}-1.751 \text { ** } \\
(0.1160)\end{array}$ \\
\hline $\operatorname{Ret}(t)$ & & $\begin{array}{c}-0.0891 \text { ** } \\
(0.0372)\end{array}$ & $\begin{array}{l}-0.0523 \\
(0.0466)\end{array}$ & $\begin{array}{c}-0.1410 \text { ** } \\
(0.0661)\end{array}$ & & & $\begin{array}{c}-0.0938^{* *} \\
(0.0441)\end{array}$ & $\begin{array}{l}-0.0565 \\
(0.0500)\end{array}$ & $\begin{array}{c}-0.1500 * * \\
(0.0657)\end{array}$ & \\
\hline $\operatorname{Ret}(t-1)$ & $-0.1190^{* * *}$ & -0.0656 & 0.0101 & -0.0555 & $-\underset{* * *}{0.2000}$ & $-\underset{* * *}{0.1190}$ & -0.0675 & 0.0081 & -0.0594 & $-\underset{* * *}{0.2010}$ \\
\hline $\begin{array}{l}\text { Constant } \\
\text { Observations } \\
R \text {-squared }\end{array}$ & $\begin{array}{c}(0.0351) \\
0.4900^{* * *} \\
(0.1440) \\
1891 \\
0.049\end{array}$ & $\begin{array}{c}(0.0570) \\
-0.0339 \\
(0.1690) \\
1891 \\
0.025\end{array}$ & $\begin{array}{c}(0.0321) \\
0.0028 \\
(0.1410) \\
1891 \\
0.011\end{array}$ & $\begin{array}{c}(0.0613) \\
-0.0311 \\
(0.2160) \\
1891 \\
0.025\end{array}$ & $\begin{array}{c}(0.0290) \\
0.4330^{* * *} \\
(0.1160) \\
1874 \\
0.213\end{array}$ & $\begin{array}{c}(0.0417) \\
0.4720^{* * *} \\
(0.1540) \\
1891 \\
0.042\end{array}$ & $\begin{array}{c}(0.0565) \\
-0.0298 \\
(0.1450) \\
1891 \\
0.022\end{array}$ & $\begin{array}{c}(0.0326) \\
0.0030 \\
(0.1490) \\
1891 \\
0.010\end{array}$ & $\begin{array}{c}(0.0505) \\
-0.0267 \\
(0.1750) \\
1891 \\
0.021\end{array}$ & $\begin{array}{c}(0.0305) \\
0.4130 * * * \\
(0.1050) \\
1874 \\
0.211\end{array}$ \\
\hline
\end{tabular}

Notes: This table reports the regression results for the BNY ADR Index daily returns on the FEARS and the New FEARS indices for the time period from 1 July 2004 to 30 December 2011. The dependent variables are contemporaneous returns (columns 1 and 5) and future returns (columns 2, 3, 6, and 7). The cumulative returns are for the first 2 days (columns 4 and 8). The independent variables are the FEARS index and the New FEARS index, and a set of control variables including the implied volatility of the S\&P 500 (VIX) index, the changes in the Economic Public Uncertainty ( $\triangle \mathrm{EPU}$ ) index, the changes in the Arouba-Diebold-Scotti business conditions index ( $\triangle \mathrm{ADS})$, and lagged returns up to five lags (only lags at time $t$ and $t-1$ are reported, others are available upon request). The standard errors are bootstrapped and displayed in parentheses. ${ }^{*}, * *$, and ${ }^{* * *}$ denote significance at the $10 \%, 5 \%$, and $1 \%$ levels, respectively.

In Table 7, we address concerns related to the potential serial autocorrelation in the error terms of the main regression model. It may be plausible that previous returns or omitted variables influence same day returns and the New FEARS alike (i.e., previous day returns). To alleviate such concerns, we estimate the main regression model using the Newey and West (1994) covariance matrix estimator. This non-parametric method automatically selects the number of autocovariances to use in computing a heteroskedasticity and autocorrelation consistent covariance matrix. This procedure is asymptotically equivalent to one that is optimal under a mean squared error loss function.

Table 7. New FEARS and the BNY ADR Index, estimated with Newey and West's (1994) standard errors.

\begin{tabular}{|c|c|c|c|c|c|c|c|c|}
\hline Independent & (1) & (2) & (3) & (4) & (5) & (6) & (7) & (8) \\
\hline Variables & $\operatorname{Ret}(t)$ & $\operatorname{Ret}(t)$ & $\operatorname{Ret}(t)$ & $\operatorname{Ret}(t)$ & $\operatorname{Ret}(t)$ & $\operatorname{Ret}(t)$ & $\operatorname{Ret}(t)$ & Ret $(t)$ \\
\hline New FEARS & $\begin{array}{c}-0.3230 \text { ** } \\
(0.1330)\end{array}$ & $\begin{array}{c}-0.3060 * * \\
(0.1320)\end{array}$ & $\begin{array}{c}-0.3280 * * \\
(0.1380)\end{array}$ & $\begin{array}{c}-0.3250 \text { ** } \\
(0.1340)\end{array}$ & $\begin{array}{c}-0.2860 * * * \\
(0.1040)\end{array}$ & $\begin{array}{c}-0.2590 \text { *** } \\
(0.0977)\end{array}$ & $\begin{array}{c}-0.2900 * * * \\
(0.1060)\end{array}$ & $\begin{array}{c}-0.2890 * * * \\
(0.1040)\end{array}$ \\
\hline VIX & $\begin{array}{c}-0.0216^{* * *} \\
(0.0064)\end{array}$ & $\begin{array}{c}-0.0180 * * * \\
(0.0050)\end{array}$ & $\begin{array}{c}-0.0193^{* * *} \\
(0.0054)\end{array}$ & $\begin{array}{l}-0.0203^{* * *} \\
(0.0060)\end{array}$ & $\begin{array}{c}-0.0215^{* * *} \\
(0.0058)\end{array}$ & $\begin{array}{c}-0.0180^{* * *} \\
(0.0050)\end{array}$ & $\begin{array}{c}-0.0199 * * * \\
(0.0054)\end{array}$ & $\begin{array}{c}-0.0206^{* * *} \\
(0.0058)\end{array}$ \\
\hline$\triangle \mathrm{EPU}$ & $\begin{array}{l}0.00003 \\
(0.0006)\end{array}$ & $\begin{array}{c}0.0002 \\
(0.0005)\end{array}$ & $\begin{array}{c}0.0001 \\
(0.0005)\end{array}$ & $\begin{array}{l}0.00004 \\
(0.0006)\end{array}$ & $\begin{array}{c}0.0001 \\
(0.0004)\end{array}$ & $\begin{array}{c}0.0003 \\
(0.0004)\end{array}$ & $\begin{array}{c}0.0002 \\
(0.0004)\end{array}$ & $\begin{array}{c}0.0001 \\
(0.0004)\end{array}$ \\
\hline$\triangle \mathrm{ADS}$ & $\begin{array}{l}-3.5660 \\
(3.4460)\end{array}$ & $\begin{array}{l}-3.1130 \\
(2.8050)\end{array}$ & $\begin{array}{l}-3.2970 \\
(3.0160)\end{array}$ & $\begin{array}{l}-3.3990 \\
(3.2460)\end{array}$ & $\begin{array}{l}-3.6850 \\
(3.3470)\end{array}$ & $\begin{array}{l}-3.3130 \\
(2.8290)\end{array}$ & $\begin{array}{l}-3.5510 \\
(3.1160)\end{array}$ & $\begin{array}{l}-3.5930 \\
(3.2400)\end{array}$ \\
\hline $\operatorname{Ret}(t-1)$ & $\begin{array}{c}-0.0922 * * * \\
(0.0219)\end{array}$ & & $\begin{array}{c}-0.0844^{* * *} \\
(0.0200)\end{array}$ & $\begin{array}{c}-0.0897^{* * *} \\
(0.0221)\end{array}$ & $\begin{array}{c}-0.1430 * * * \\
(0.0274)\end{array}$ & & $\begin{array}{c}-0.1380^{* * *} \\
(0.0262)\end{array}$ & $\begin{array}{c}-0.1410^{* * * *} \\
(0.0281)\end{array}$ \\
\hline$\Delta$ FX U.S. T-W & & & & & $\begin{array}{c}-1.3360 * * * \\
(0.1620)\end{array}$ & $\begin{array}{c}-1.2580 * * * \\
(0.1360)\end{array}$ & $\begin{array}{c}-1.3390 * * * \\
(0.1620)\end{array}$ & $\begin{array}{c}-1.3370 * * * \\
(0.1600)\end{array}$ \\
\hline Constant & $\begin{array}{c}0.4410^{* * *} \\
(0.1050)\end{array}$ & $\begin{array}{c}0.3710^{* * *} \\
(0.0816)\end{array}$ & $\begin{array}{c}0.3950 * * * \\
(0.0892)\end{array}$ & $\begin{array}{c}0.4140 * * * \\
(0.0994)\end{array}$ & $\begin{array}{c}0.4390 * * * \\
(0.0947)\end{array}$ & $\begin{array}{c}0.3680^{* * *} \\
(0.0819)\end{array}$ & $\begin{array}{c}0.4060 * * * \\
(0.0891)\end{array}$ & $\begin{array}{c}0.4200 * * * \\
(0.0957)\end{array}$ \\
\hline Observations & 3268 & 3273 & 3272 & 3271 & 3241 & 3246 & 3245 & 3244 \\
\hline$R$-squared & 0.035 & 0.019 & 0.026 & 0.030 & 0.162 & 0.140 & 0.159 & 0.160 \\
\hline
\end{tabular}

Notes: This table reports the regression results for the BNY ADR Index daily returns to the New FEARS index using Newey and West's (1994) standard errors. The dependent variable is the contemporaneous returns for the BNY Mellon ADR Index. The independent variable is the New FEARS index and a set of control variables including the implied volatility of the S\&P 500 (VIX) index, the changes in the Economic Public Uncertainty ( $\triangle \mathrm{EPU}$ ) index, the changes in the Arouba-Diebold-Scotti business conditions index ( $\triangle \mathrm{ADS})$, lagged returns up to five lags (only lags at time $t$ and $t-1$ are reported, others are available upon request), and the changes in the exchange rate between the U.S. dollar and a basket of trade-weighted currencies ( $\triangle$ FX U.S. T-W). The standard errors are robust and displayed in parentheses.

${ }^{* *}$, and ${ }^{* * *}$ denote significance at the $5 \%$, and $1 \%$ levels, respectively. 
The results show that regardless of the model utilized, the New FEARS index has a negative impact on the BNY ADR Index returns, with statistically significant negative coefficients. In Model 1, a one standard deviation increase in the New FEARS is associated with a 12.6 basis points decrease in the ADR Index returns. In column 5 , we include the trade-weighted changes in the exchange rate, the New FEARS coefficient is less prominent but still affects daily returns by 11.1 basis points in response to a one standard deviation increase in the New FEARS.

\section{Conclusions}

Using a daily index composed of historical internet search queries for a set of negative (e.g., recession, depression) economic search terms, this study shows that increases in the volume of searches like "recession" and "crisis" have a negative effect on the returns of aggregate indices of cross-listed firms. The results show the negative effect of this novel measure of sentiment on contemporaneous ADR index returns and a subsequent next day reversal. The results are consistent when we use ADR equally- and value-weighted portfolios, regional ADR indices for Asia, Europe, and Latin America indices as well. When comparing the coefficients, this study shows that Latin American ADRs are generally more affected by changes in the New FEARS index relative to European and Asian countries. Although ADRs can be considered a long-term diversification tool for many investors, these securities are susceptible to contemporaneous increases in U.S. investors' uncertainty and pessimism. One direct implication of our empirical evidence is the importance of U.S. investor sentiment in the asset price models for foreign securities. These findings are of particular relevance for short-term and long-term investors and portfolio managers alike, and are consistent with Frugier (2016), who shows that investor sentiment can be profitably used by practitioners. Overall, we find our results to be consistent with those of Da et al. (2015) and Gao et al. (2020), and other literature that explores the FEARS and its effect on asset prices. Our results show, that similar to U.S. domestic stocks, cross-listed security indices exhibit a contemporaneous negative return as the negative sentiment increases among U.S. investors. These findings support that U.S. investors sentiment spills over to foreign securities in the short term with a subsequent next-day reversal effect in spite of the long-term diversification benefits reported by others.

This study expands the literature that utilizes high-frequency investor sentiment measures derived from internet usage data. The use of high-frequency investor sentiment measures is emerging as a useful source of information for understanding the effects of human behavior on financial markets. We expand the literature on the spillover effects of U.S. investors' sentiment on foreign securities, using ADR indices as our proxy for international stocks. We find that although ADRs represent a piece of ownership in an underlying asset originally traded in another country, their aggregate market index returns are equally contemporaneously affected similarly to any other U.S. domestic stock.

As with any other research project, this study is not without its limitations. Some might consider it appropriate to build a sentiment for each ADR index region. However, that would present additional technical and semantic challenges to be addressed separately. For example, given the cultural and language differences for each country, it would be difficult to match search terms that could be directly comparable for economic or financial interpretation. Furthermore, the search terms used to build our measure of sentiment may not have the same translation or cultural connotation, e.g., "social security office" is the name of the U.S. agency in charge of social security benefits and social insurance programs, which may not have an equivalent agency in every country that has stocks cross-listed in the U.S. markets.

Future research could further expand on the use of SVI-driven investor sentiment that is focused on search terms that are particularly relevant to cross-listed securities. Further studies could also focus on explaining the difference in the coefficients between Latin American, European, or Asian indices, and even study individual country ADR indices. Finally, it would be interesting to consider the effects of netnography in the creation of 
the sentiment indices, and understanding and controlling for the characteristics of those who perform such searches would give a much richer insight to building the sentiment measure. Some other relevant topics that can also be explored using the SVI approach are sustainability, environmental, social, and governance (ESG).

Author Contributions: Conceptualization, J.P.G.P.; methodology, J.P.G.P.; validation, J.P.G.P. and D.P.L.; formal analysis, J.P.G.P.; resources, J.P.G.P. and D.P.L.; data curation, J.P.G.P.; writing-original draft preparation, J.P.G.P.; writing—review and editing, D.P.L.; supervision, J.P.G.P. and D.P.L. All authors have read and agreed to the published version of the manuscript.

Funding: This research received no external funding.

Institutional Review Board Statement: Not applicable.

Informed Consent Statement: Not applicable.

Data Availability Statement: The data presented in this study are available on request from the corresponding author. Most of the data are not publicly available due to copyright from the sources.

Acknowledgments: The authors would like to thank four anonymous reviewers whose comments and suggestions helped improve and clarify this manuscript. Any remaining errors are their own.

Conflicts of Interest: The authors declare no conflict of interest.

\section{Notes}

Da et al. (2015) identify these search terms as having the highest negative correlation with stock market returns from July 2004 to December 2011. Even though our findings are consistent with theirs, there is a possibility that the list of search terms could have changed by including a longer data set in our study.

2 The paper by Qiu and Welch (2004) refers to an earlier version of Baker and Wurgler (2006) while it was still a working paper in 2004 .

3 These are the top 30 search terms with the highest negative correlation with the S\&P 500 from 1 January 2004 to 31 December 2011. Search terms like "gold prices" have a positive semantic acception, however, it is well known that gold is a commodity considered a safe haven by many investors. Meaning that when investors have negative expectations on stock returns, they sell stocks and buy assets like gold. Da et al. (2015) offers a more extensive discussion in this regard.

4 This index contains almost every American Depositary Receipt available in the market.

5 This data is available for download through https:/ / fred.stlouisfed.org/series/DTWEXB (accessed on 16 March 2018).

6 More information about ETF's using BNY Mellon ADR indices as benchmarks can be found at https://www.adrbnymellon.com /assets/resources/etf_factsheet-jan_2017.pdf (accessed on 16 March 2018).

7 This data is available for download at http://www.cboe.com/micro/vix/historical.aspx (accessed on 15 March 2018).

8 We tested for the stationarity condition of the VIX series in levels using the Augmented Dickey-Fuller test. The null hypothesis of the presence of a unit root is rejected with a $t$-statistic of -5.978 .

9 This data is available for download at https://www.philadelphiafed.org/research-and-data/real-time-center/business-condit ions-index (accessed on 15 March 2018).

10 This data is available for download at http:/ / www.policyuncertainty.com/us_daily.html (accessed on 15 March 2018).

11 The correlation coefficient between the New FEARS and the FEARS from Da et al. (2015) is 0.43 and is available upon request.

12 We used 252 trading days as the average to calculate the annualized returns and U.S. dollar appreciation.

13 A potential explanation for this difference, is that their period of study (2004-2011) was highly marked by the 2008 financial crisis. In this study the period is expanded from 2004 to 2016, in which the 2008 financial crisis is less pronounced.

\section{References}

Alaganar, Vaira, and Ramaprasad Bhar. 2001. Diversification gains from American depositary receipts and foreign equities: Evidence from Australian stocks. Journal of International Financial Markets, Institutions \& Money 11: 97-113.

Baker, Malcom, and Jeffrey Wurgler. 2006. Investor sentiment and the cross-section of stock returns. The Journal of Finance 61: 1645-80. [CrossRef]

Baker, Malcom, and Jeffrey Wurgler. 2007. Investor Sentiment in the Stock Market. The Journal of Economic Perspectives 21: 129. [CrossRef]

Baker, Scott, Nicholas Bloom, and Steven Davis. 2015. Measuring economic policy uncertainty. The Quarterly Journal of Economics 131: 1593-1636. [CrossRef] 
Barberis, Nicholas, Andrei Shleifer, and Robert Vishny. 1998. A model of investor sentiment. Journal of Financial Economics 49: 307-43. [CrossRef]

Bathia, Deven, Don Bredin, and Dirk Nitzsche. 2016. International sentiment spillovers in equity returns. International Journal of Finance $\mathcal{E}$ Economics 21: 332-59.

Beckmann, Klaus S., Thanh Ngo, and Daphne Wang. 2015. The informational content of ADR mispricing. Journal of Multinational Financial Management 32: 1-14. [CrossRef]

Brown, Gregory W., and Michael T. Cliff. 2004. Investor sentiment and the near-term stock market. Journal of Empirical Finance 11: 1-27. [CrossRef]

Burgraff, Tobias, Toan Lulu Duc Huynh, Markus Rudolf, and Mei Wang. 2020. Do FEARS drive Bitcoin? Review of Behavioral Finance 13: 229-58. [CrossRef]

Da, Zhi, Joseph Engelberg, and Pengjie Gao. 2011. In search of attention. The Journal of Finance 66: 1461-99. [CrossRef]

$\mathrm{Da}$, Zhi, Joseph Engelberg, and Pengjie Gao. 2015. The sum of all fears investor sentiment and asset prices. Review of Financial Studies 28: 1-32. [CrossRef]

De Long, J. Bradford, Andrei Shleifer, Lawrence H. Summers, and Robert J. Waldmann. 1990. Noise trader risk in financial markets. Journal of Political Economy 98: 703-38. [CrossRef]

Ely, David, and Mehdi Salehizadeh. 2001. American depositary receipts: An analysis of international stock price movements. International Review of Financial Analysis 10: 343-63. [CrossRef]

Engelbert, Joseph. "Joey Engelberg-Professor of Finance" Website. Available online: http:/ /rady.ucsd.edu/faculty/directory/engelber $\mathrm{g} / \mathrm{pub}$ / portfolios/research.htm (accessed on 15 March 2018).

Frugier, Alain. 2016. Returns, volatility and investor sentiment: Evidence from European stock markets. Research in International Business and Finance 38: 45-55. [CrossRef]

Gagnon, Louis, and George Andrew Karolyi. 2010. Do International Cross-Listings Still Matter? Evidence on Financial Globalization and Crises. Edited by Thorsten Beck, Sergio Schmukler and Stijn Claessens. Amsterdam: Elsevier North-Holland Publishers. Available online: https: / / ssrn.com/abstract=1638197 (accessed on 10 October 2017).

Gao, Zhenyu, Haohan Ren, and Bohui Zhang. 2020. Googling investor sentiment around the world. Journal of Financial and Quantitative Analysis 55: 549-80. [CrossRef]

Grossmann, Axel, Teofilo Ozuna, and Marc W. Simpson. 2007. ADR mispricing: Do costly arbitrage and consumer sentiment explain the price deviation? Journal of International Financial Markets, Institutions \& Money 17: 361-71.

Hwang, Byoung-Hyoun. 2011. Country-specific sentiment and security prices. Journal of Financial Economics 100: 382-401. [CrossRef]

Irresberger, Felix, Janina Mühlnickel, and Gregor NF Weiß. 2015. Explaining bank stock performance with crisis sentiment. Journal of Banking \& Finance 59: 311-29.

Jiang, Christine X. 1998. Diversification with American depository receipts: The dynamics and the pricing factors. Journal of Business Finance $\mathcal{E}$ Accounting 25: 683-99.

Kabir, M. Humayun, M. Kabir Hassan, and Neal Maroney. 2011. International diversification with American depository receipts (ADRs). Pacific-Basin Finance Journal 19: 98-114. [CrossRef]

Keynes, John Maynard. 1936. The General Theory of Interest, Employment and Money. London: MacMillan.

Kostopoulos, Dimitrios, Steffen Meyer, and Charline Uhr. 2020. Google search volume and individual investor trading. Journal of Financial Markets 49: 100544. [CrossRef]

Madura, Jeff, and Nivine Richie. 2007. Global valuation of equity: One market correcting another. International Journal of Managerial Finance 3: 178-90. [CrossRef]

Newey, Whitney K., and Kenneth D. West. 1994. Automatic Lag Selection in Covariance Matrix Estimation. Review of Economic Studies 61: 631-53. [CrossRef]

Perez-Liston, Daniel, and Juan Pablo Gutierrez. 2018. Dynamic analysis of sin stocks and investor sentiment. International Journal of Managerial Finance 14: 558-73. [CrossRef]

Perez-Liston, Daniel, Daniel Huerta-Sanchez, and Juan Gutierrez. 2018. Do domestic sentiment and the spillover of US investor sentiment impact Mexican stock market returns? Journal of Emerging Market Finance 17: 185-212. [CrossRef]

Peterburgsky, Stanley, and Yini Yang. 2013. Diversification potential of ADRs, country funds and underlying stocks across economic conditions. Applied Financial Economics 23: 199-219. [CrossRef]

Qiu, Lily, and Ivo Welch. 2004. Investor Sentiment Measures (No. w10794). Unpublished working paper. Brown University.

Schaub, Mark. 2013. Latin American ADR performance: How do issue type and issue date affect long term excess returns? International Journal of Managerial Finance 9: 4-12. [CrossRef]

Siganos, Antonio, Evangelos Vagenas-Nanos, and Patrick Verwijmeren. 2014. Facebook's daily sentiment and international stock markets. Journal of Economic Behavior E Organization 107: 730-43.

Singer, Eleanor. 2002. The use of incentives to reduce nonresponse in household surveys. Survey Nonresponse 51: $163-77$.

Suh, Jungwon. 2003. ADRs and U.S. Market Sentiment. The Journal of Investing 12: 87-95. [CrossRef]

Tetlock, Paul. C. 2007. Giving content to investor sentiment: The role of media in the stock market. The Journal of Finance 62: 1139-68. [CrossRef]

Tetlock, Paul C., Maytal Saar-Tsechansky, and Sofus Macskassy. 2008. More than words: Quantifying language to measure firms' fundamentals. The Journal of Finance 63: 1437-67. [CrossRef] 
Verma, Rahul, and Gökçe Soydemir. 2006. The impact of US individual and institutional investor sentiment on foreign stock markets. The Journal of Behavioral Finance 7: 128-44. [CrossRef]

Vozlyublennaia, Nadia. 2014. Investor attention, index performance, and return predictability. Journal of Banking E Finance 41: 17-35.

World Bank. 2020. Individuals using the internet in the United States. Available online: https://databank.worldbank.org/source/worl d-development-indicators (accessed on 12 October 2020).

$\mathrm{Wu}$, Qinqin, Ying Hao, and Jing Lu. 2017. Investor sentiment, idiosyncratic risk, and mispricing of American Depository Receipt. Journal of International Financial Markets, Institutions \& Money 51: 1-14.

Zhang, Wei, Xiao Li, Dehua Shen, and Andrea Teglio. 2016. Daily happiness and stock returns: Some international evidence. Physica A: Statistical Mechanics and Its Applications 460: 201-9. [CrossRef] 